Tropical Journal of Pharmaceutical Research May 2020; 19 (5): 989-994

ISSN: $1596-5996$ (print); 1596-9827 (electronic) (C) Pharmacotherapy Group, Faculty of Pharmacy, University of Benin, Benin City, 300001 Nigeria.

\title{
Vitexin alleviates neuropathic pain in a mouse chronic constriction injury model by inactivation of NF-KB
}

\author{
Wentong Xu${ }^{1}$, Xueli Zhu ${ }^{1 *}$, Gonghao Zhan², Liangyu Sheng ${ }^{3}$, Yanwei Chen ${ }^{3}$ \\ ${ }^{1}$ Department of Pain Rehabilitation, Lanxi People's Hospital, Jinhua City, Zhejiang Province 321100, ${ }^{2}$ Department of Pain, the \\ Second Affiliated Hospital of Wenzhou Medical University, Wenzhou City, Zhejiang Province 325003, ${ }^{3}$ Department of Pain, \\ Lanxi People's Hospital, Jinhua City, Zhejiang Province 321100, China
}

*For correspondence: Email: XueliZhudhj@163.com; Tel: +86-57988669782

Sent for review: 8 February 2020

Revised accepted: 26 April 2020

\begin{abstract}
Purpose: To investigate the therapeutic effect of vitexin on neuropathic pain (NP) in a mouse model of chronic constriction injury $(\mathrm{CCl})$.

Methods: The $\mathrm{CCl}$ model was established by four chronic ligatures in the sciatic nerve. Vitexin was intraperitoneally administered (10 mg/kg, once daily) for 21 days. Mechanical withdrawal threshold (MWT) and paw withdrawal latency (PWL) were determined before and after the establishment of $\mathrm{CCI}$ model. The spinal cords were collected to measure $m R N A$ levels by reverse-transcriptase polymerase chain reaction (RT-PCR) enzyme-linked immunosorbent assay (ELISA). Western blot was used to examine protein expression levels.

Results: Vitexin reversed the CCl-induced reduction in MWT and PWL values, indicating that it lowered mechanical hypersensitivity response and hyperalgesia caused thermal stimulation $(p<0.05)$. The elevated levels of IL-6, IL-1 3 , and TNF $\alpha$ observed in CCl-treated mice were also inhibited by vitexin, suggesting that it suppressed pro-inflammatory cytokines. Moreover, vitexin attenuated CCl-induced activation of NF-KB signaling in CCl-treated mice $(p<0.05)$.

Conclusion: Vitexin alleviates NP by inhibiting pro-inflammatory cytokines and NF-kB signaling in $\mathrm{CCl}$ treated mice. Thus, it is a potential target for NP treatment.
\end{abstract}

Keywords: Vitexin, Neuropathic pain, Chronic constriction injury, Mechanical hypersensitivity, Hyperalgesia, NF-KB

\begin{abstract}
This is an Open Access article that uses a fund-ing model which does not charge readers or their institutions for access and distributed under the terms of the Creative Commons Attribution License (http://creativecommons.org/licenses/by/4.0) and the Budapest Open Access Initiative (http://www.budapestopenaccessinitiative.org/read), which permit unrestricted use, distribution, and reproduction in any medium, provided the original work is properly credited.

Tropical Journal of Pharmaceutical Research is indexed by Science Citation Index (SciSearch), Scopus, International Pharmaceutical Abstract, Chemical Abstracts, Embase, Index Copernicus, EBSCO, African Index Medicus, JournalSeek, Journal Citation Reports/Science Edition, Directory of Open Access Journals (DOAJ), African Journal Online, Bioline International, Open-J-Gate and Pharmacy Abstracts
\end{abstract}

\section{INTRODUCTION}

Pain result from a lesion or somatosensory nervous system dysfunction is called as neuropathic pain (NP) [1]. Over the past decades, the incidence of NP has remarkably increased, and about $15-25 \%$ of patients with chronic pain have NP [2]. Moreover, NP patients have poorer quality of life than that with nociceptive pain [3]. The increased occurrence of NP is largely attributed to a lack of effective medications. Therefore, it is necessary to discover effective drugs for NP patients.

Vitexin is a type of flavonoid extracted from the leaves of Crataegus pinnatifida (hawthorn) [4]. Previous studies have demonstrated that vitexin exhibits pharmacological effects on tumors and 
viruses and in the cardiovascular system and neurons [5-8]. In particular, a recent study reported that vitexin has potency on pain relief by exerting analgesic effects on inflammatory pain through inhibitingTRPV1 and inflammatory responses [9]. Postoperative pain also could be attenuated by vitexin through its effects on opioid and gamma-aminobutyric acid $(\mathrm{GABA})_{\mathrm{A}}$ receptors [10]. However, the potential beneficial effects of vitexin on NP remain unclear.

The NF-kB signaling pathway is closely related to multiple biological processes through regulating cytokine expression and immune responses [11]. The regulation of inflammatory cytokine gene expression caused by the activated NF-kB pathway have been proved to affect pain behavior [12]. Through inhibiting NF-kB signaling, dexmedetomidine relieved NP following chronic constriction injury (CCI) [13]. Considering the conclusion that vitexin could suppress the NF-kB pathway [14], it is hypothesized that vitexin may ameliorate NP by suppressing NF-kB activation.

To verify it, a $\mathrm{CCl}$ mouse model was established and spinal cords were collected to determine whether vitexin treatment could attenuate mechanical hypersensitivity response and hyperalgesia to thermal stimulation by inhibition of pro-inflammatory cytokine expression and NF$\mathrm{KB}$ signaling.

\section{EXPERIMENTAL}

\section{Animals}

C57BL/6 mice (male, 5-week-old) from Shanghai SLAC Laboratory Animal Co., Ltd (Shanghai, China) were housed in specific pathogen-free rooms at $22 \pm 2^{\circ} \mathrm{C}$ with $60 \pm 5 \%$ humidity. Animal experiments were performed according to international guidelines [15], and were approved by the institutional ethics committee (approval no. L20190131).

\section{CCI model}

Intraperitoneal chloral hydrate (4\%, $10 \mu \mathrm{L} / \mathrm{g})$ was used for anesthesia. An incision was made in the skin, and about $10 \mathrm{~mm}$ of sciatic nerve was gently exposed via blunt scissors, opening a gap between the biceps femoris muscles and gluteus superficialis. Four loose catgut 6.0 ligatures (1 $\mathrm{mm}$ apart) were tied near the trifurcation of sciatic nerve. The muscle layer and skin were closed with sutures. Then, the mice were placed onto an electric blanket $\left(37^{\circ} \mathrm{C}\right)$ until they regained consciousness.
Mice were grouped ( $\mathrm{n}=10 /$ group): 1) sham, 2) $\mathrm{CCl}$, and 3) $\mathrm{CCl}+$ Vitexin (Vit). $\mathrm{CCl}+$ Vit, mice after $\mathrm{CCl}$ surgery were intraperitoneally injected with vitexin $(10 \mathrm{mg} / \mathrm{kg}$, Tauto Biotechnology Co., Ltd., Shanghai, China) once daily for 21 days. Sham, no ligatures were tied near the trifurcation of sciatic nerve and received normal saline as blank control. $\mathrm{CCl}$, mice after $\mathrm{CCl}$ surgery received normal saline as negative control. The spinal cord was collected for following analysis.

\section{Evaluation of MWT and PWL}

MWT and PWL were performed 1 day prior to surgery (-1 day) and 1, 7, 14, 21 days after surgery. MWT was assessed with the aid of von Frey filaments. Mice were placed on a wire mesh and acclimatized to surroundings for $45 \mathrm{~min}$. A $0.6 \mathrm{~g}$ filament was used to touch the plantar surface of mice hide paw. If the mouse reacted by withdrawing the stimulated hind paw or not, filament thickness was increased or decreased, respectively. This procedure was repeated eight times on each hind paw.

PWL was assessed by Hargreaves method. Mice were placed on a glass surface and acclimatized to surroundings for $45 \mathrm{~min}$. The plantar surface of mice hind paw was exposed to a radiant heat source (with a stimulus cut-off of $18 \mathrm{~s}$ ). Withdrawal latency was quantified by heat sensitivity, which was recorded three times on each hind paw.

\section{Real-time quantitative polymerase chain reaction (RT-qPCR)}

Total RNA was extracted from homogenized tissues, and then reverse-transcribed. RT-qPCR was performed using SYBR Green (Takara, Shiga, Japan) and normalized to GAPDH with the following primers.

\section{Assessment of pro-inflammatory cytokine}

Tissues were mechanically homogenized in RIPA buffer at $4^{\circ} \mathrm{C}$, and centrifuged. The levels of IL-1 $\beta, I L-6$, and TNF $\alpha$ in the supernatant were measured using ELISA kits ( $R$ \& D Systems, Minneapolis, MN, USA).

\section{Western blotting}

The supernatant from spinal cord homogenate was tested for protein concentration by BCA Assay (Beyotime). 30 $\mu$ g proteins were separated on SDS-PAGE and transferred to membranes (Millipore, Burlington, MA, USA)and incubated with primary antibodies (1:1000) against Toll-like receptor 4 (TLR4), inhibitor of NF-kB (IKBa), 
phosphorylated (p)-IKBa, p65, p-p65, and $\beta$-actin at $4{ }^{\circ} \mathrm{C}$ overnight. The membranes were probes with horseradish peroxidase-labeled secondary antibodies. Protein bands were visualized and analyzed. Antibodies were obtained from Abcam (Cambridge, UK).

Table 1: Sequences of primers

\begin{tabular}{|c|c|c|}
\hline $\begin{array}{l}\text { Gene } \\
\text { TNFa }\end{array}$ & \multicolumn{2}{|c|}{ Primer sequence } \\
\hline TNFa & Forward & $\begin{array}{l}\text { 5'- } \\
\text { CTTCTCATTCCTGCTTGT } \\
\text { G-3' }\end{array}$ \\
\hline & Reverse & $\begin{array}{l}\text { 5'- } \\
\text { ACTTGGTGGTTTGCTAC } \\
\text { G-3' }\end{array}$ \\
\hline \multirow[t]{2}{*}{ IL-1 $\beta$} & Forward & $\begin{array}{l}\text { 5'- } \\
\text { CCTGGGCTGTCCTGATG } \\
\text { AGAG-3' }\end{array}$ \\
\hline & Reverse & $\begin{array}{l}\text { 5'- } \\
\text { TCCACGGGAAAGACACA } \\
\text { GGTA-3' }\end{array}$ \\
\hline \multirow[t]{2}{*}{ IL-6 } & Forward & $\begin{array}{l}\text { 5'- } \\
\text { GGCGGATCGGATGTTGT } \\
\text { GAT-3' }\end{array}$ \\
\hline & Reverse & $\begin{array}{l}\text { 5'- } \\
\text { GGACCCCAGACAATCG } \\
\text { GTTG-3' }\end{array}$ \\
\hline \multirow[t]{2}{*}{ GAPDH } & Forward & $\begin{array}{l}\text { 5'- } \\
\text { CAATGTGTCCGTCGTGG } \\
\text { ATCT-3' }\end{array}$ \\
\hline & Reverse & $\begin{array}{l}\text { 5'- } \\
\text { GTCCTCAGTGTAGCCCA } \\
\text { AGATG-3' }\end{array}$ \\
\hline
\end{tabular}

Statistical analysis

All experiments were performed in triplicate, the data expressed as mean $\pm S D$, and analyzed using ANOVA with SPSS 16.0 software (SPSS Inc, Chicago, IL, USA). $P<0.05$ was considered statistically significantly.

\section{RESULTS}

Vitexin attenuated $\mathrm{CCl}$-induced mechanical
hypersensitivity response

To investigate the therapeutic value of vitexin on $\mathrm{NP}$, a $\mathrm{CCl}$ mice model was established by four chronic ligatures in the sciatic nerve, MWT value was measured. The significantly decreased MWT value was observed in $\mathrm{CCl}$ mice than sham group, indicating marked mechanical hypersensitivity response (Figure 1). However, the reduction of MWT was partially reversed by vitexin from day 1 to 21 (Figure 1, $p<0.01$ ). These results demonstrated that vitexin alleviated $\mathrm{CCl}$-induced mechanical hypersensitivity response.

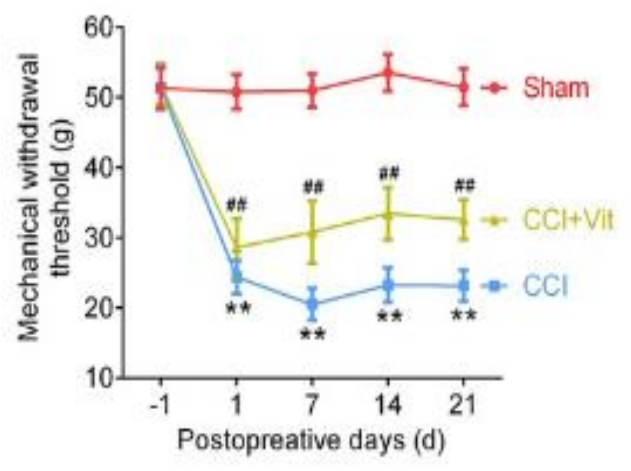

Figure 1: Effect of vitexin on $\mathrm{CCl}$-induced mechanical hypersensitivity response. At 1, 7, 14, 21 days after $\mathrm{CCl}$, MWT value in mice was measured; ${ }^{* *} p$ and \#\#p < 0.01 vs. sham $/ \mathrm{CCl}$ group

\section{Vitexin ameliorated $\mathrm{CCl}$-induced hyperalgesia response to thermal stimulation}

Thermal hyperalgesia was also evaluated in the $\mathrm{CCl}$ mouse model. The value of PWL was decreased markedly after $\mathrm{CCl}$ surgery when compared to sham group (Figure 2, $p<0.01$ ). On the other hand, vitexin treatment remarkably attenuated $\mathrm{CCl}$-induced hypersensitivity in mice (Figure 2, $p<0.01$ ).

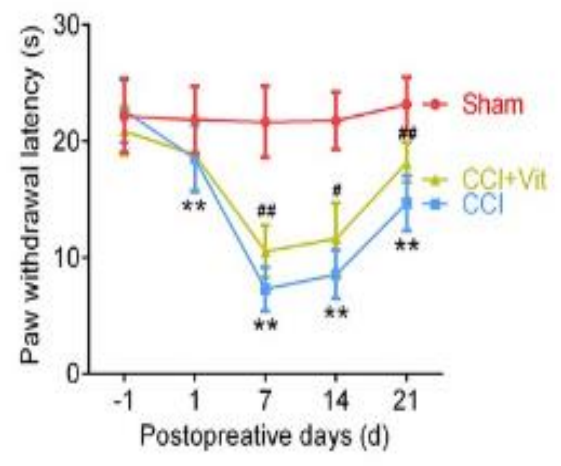

Figure 2: Effect of vitexin on $\mathrm{CCl}$-induced hyperalgesia to thermal stimulation. At 7, 14, 21 days after $\mathrm{CCl}$, the value of PWL was measured; ${ }^{* *} p$ and $\#$ \#p 0.01 vs. sham/CCl group

\section{Vitexin reduced pro-inflammatory cytokine levels in $\mathrm{CCl}$ mice}

Whether vitexin has anti-inflammatory abilities on $\mathrm{CCl}$ mice were evaluated. The mRNA expression and levels of IL-6, IL-1 $1 \beta$, and TNF $\alpha$ were higher in the spinal cord from $\mathrm{CCl}$ mice than sham mice. Notably, these levels decreased after vitexin treatment (Figure $3 \mathrm{~A}$ and $\mathrm{B}, p<0.01$ ). These results indicate that the therapeutic effect of vitexin on NP occurs probably by inhibiting proinflammatory cytokines. 
A
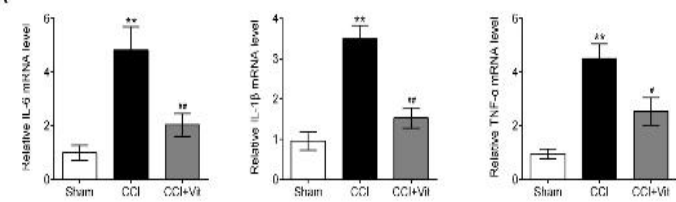

B
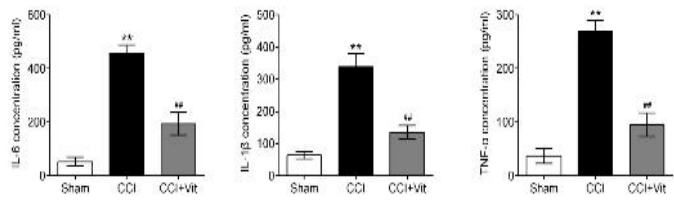

Figure 3: Effect of vitexin on $\mathrm{CCl}$-induced proinflammatory cytokine levels in mice. The relative mRNA expression $(A)$ and levels $(B)$ in mice $(n=5)$ were detected by RT-qPCR and ELISA; ${ }^{* *} p$ and \#\#p < 0.01 vs. sham/CCl group

Vitexin suppressed NF-kB signaling in $\mathrm{CCl}$ mice

Following analysis examined the expression of NF-kB pathway, an essential transduction signal that regulates pro-inflammatory cytokine expression. Treatment of $\mathrm{CCl}$ significantly downregulated $I \kappa B \alpha$, but increased the phosphorylated levels of p65 and IkBa in $\mathrm{CCl}$ mice. Vitexin treatment effectively inactivated NF-kB pathway (Figure 4). Thus, vitexin alleviated NP in CCl-mice through inhibition of NF-kB pathway.


Figure 4: Effect of vitexin on NF-kB pathway in $\mathrm{CCl}$ treated mice; ${ }^{* *} p$ and $\# \#<0.01$ vs. sham/CCl group. Protein levels were measured by western blot; ${ }^{* *} p<$ 0.01 vs. sham group; \#\#p<0.01 vs. $\mathrm{CCl}$ group

\section{DISCUSSION}

Here, vitexin was firstly found to reverse the reductions in $\mathrm{CCl}$-induced $\mathrm{MWT}$ and $\mathrm{PWL}$ values. Moreover, the enhanced expressions of IL-6, IL-1 $\beta$, and TNF $\alpha$ in spinal cord induced by $\mathrm{CCl}$ was also inhibited by vitexin. Mechanistically, vitexin exerted therapeutic effects on NP through the inactivation of NF-KB signaling.

The common symptoms of NP patients are depression, anxiety, or cognitive deficits [16].
Similarly, cognitive impairment could be induced in a $\mathrm{CCl}$ model [17], which is considered an ideal experimental method to establish NP. In the present study, the MWT and PWL were decreased by $\mathrm{CCl}$, suggesting that the model was successfully established [18]. Furthermore, vitexin alleviated MWT and PWL in $\mathrm{CCl}$ model, suggesting its potential therapeutic effects on NP.

Following injury to the nervous system, cytokines serve as intercellular messengers [19,20]. Proinflammatory cytokines have been found to induce or facilitate NP, while inhibition of proinflammatory cytokines alleviates NP in an animal model [21]. Following $\mathrm{CCl}$, TNFa levels were increased in injured nerves, which contributes to the immune response and NP progression [22]. Studies have shown that IL-1 $\beta$ modulates pain sensitivity and contributes to immune responses after nerve injury [13]. Likewise, IL-6 promotes mechanical allodynia following $\mathrm{CCl}$ [23]. In this study, vitexin markedly reduced the overexpressions of IL- $6, \mathrm{IL}-1 \beta$, and TNFa in the $\mathrm{CCl}$ model. Therefore, the analgesic effect of vitexin on NP was probably mediated through downregulating pro-inflammatory cytokines.

The NF-kB pathway has a crucial role in nociception [24]. In the dorsal root ganglia and spinal cord tissues from multiple animal models of neuropathy, NF-KB signals are activated, thereby contributing to pain development [24]. Inhibitors of NF-KB signaling pathway not only attenuated mechanical hypersensitivity response and hyperalgesia to thermal stimulation in a $\mathrm{CCl}$ model but also enhanced analgesia from morphine [25,26]. Vitexin can inhibit NF-kB pathway to show anti-tumor activity in nasopharyngeal carcinoma [14]. In the present study, vitexin significantly inhibited NF-kB signaling in $\mathrm{CCl}$-treated mice, revealing the molecular mechanisms underlying the therapeutic effect of vitexin on NP.

\section{CONCLUSION}

Vitexin alleviates NP by decreasing proinflammatory cytokine levels and inhibiting NF-KB signaling in the spinal cord. Therefore, vitexin is a potential candidate for NP treatment.

\section{DECLARATIONS}

\section{Conflict of interest}

No conflict of interest is associated with this work. 


\section{Contribution of authors}

We declare that this work was done by the authors named in this article and all liabilities pertaining to claims relating to the content of this article will be borne by the authors.

\section{Open Access}

This is an Open Access article that uses a funding model which does not charge readers or their institutions for access and distributed under the terms of the Creative Commons Attribution License (http://creativecommons.org/licenses/by/ 4.0) and the Budapest Open Access Initiative (http://www.budapestopenaccessinitiative.org/rea d), which permit unrestricted use, distribution, and reproduction in any medium, provided the original work is properly credited.

\section{REFERENCES}

1. Treede RD, Jensen TS, Campbell JN, Cruccu G, Dostrovsky JO, Griffin JW, Hansson P, Hughes R, Nurmikko $T$, Serra J. Neuropathic pain: redefinition and a grading system for clinical and research purposes. Neurology 2008; 70(18): 1630-1635.

2. Bouhassira $D$, Lanteri-Minet $M$, Attal $N$, Laurent $B$, Touboul C. Prevalence of chronic pain with neuropathic characteristics in the general population. Pain 2008; 136(3): 380-387.

3. Smith BH, Torrance N, Bennett MI, Lee AJ. Health and quality of life associated with chronic pain of predominantly neuropathic origin in the community. Clin $J$ Pain 2007; 23(2): 143-149.

4. Wu J, Peng W, Qin R, Zhou H. Crataegus pinnatifida: chemical constituents, pharmacology, and potential applications. Molecules 2014; 19(2): 1685-1712.

5. Yang SH, Liao PH, Pan YF, Chen SL, Chou SS, Chou MY. The novel p53-dependent metastatic and apoptotic pathway induced by vitexin in human oral cancer OC2 cells. Phytother Res 2013; 27(8): 1154-1161.

6. Dong LY, Li S, Zhen YL, Wang YN, Shao X, Luo ZG. Cardioprotection of vitexin on myocardial ischemia/reperfusion injury in rat via regulating inflammatory cytokines and MAPK pathway. Am J Chin Med 2013; 41(6): 1251-1266.

7. Chen L, Zhang B, Shan S, Zhao $X$. Neuroprotective effects of vitexin against isoflurane-induced neurotoxicity by targeting the TRPV1 and NR2B signaling pathways. Mol Med Rep 2016; 14(6): 5607-5613.

8. Yi J, Wu J-G, Wu Y-B, Peng W. Antioxidant and antiproliferative activities of flavonoids from Bidens pilosa $L$ var radiata Sch Bip. Trop J Pharm Res 2016; 15(2): 341-348.

9. Borghi SM, Carvalho TT, Staurengo-Ferrari L, Hohmann MS, Pinge-Filho $P$, Casagrande R, Verri WA, Jr. Vitexin inhibits inflammatory pain in mice by targeting TRPV1, oxidative stress, and cytokines. J Nat Prod 2013; 76(6): 1141-1149.

10. Zhu $Q$, Mao $L N$, Liu CP, Sun YH, Jiang B, Zhang $W, L i$ $J X$. Antinociceptive effects of vitexin in a mouse model of postoperative pain. Sci Rep 2016; 6:19266.

11. Shih VF, Tsui R, Caldwell A, Hoffmann A. A single NFkappaB system for both canonical and non-canonical signaling. Cell Res 2011; 21(1): 86-102.

12. Sakaue G, Shimaoka M, Fukuoka $T$, Hiroi $T$, Inoue $T$, Hashimoto N, Sakaguchi T, Sawa Y, Morishita R, Kiyono $\mathrm{H}$ et al. NF-kappa $B$ decoy suppresses cytokine expression and thermal hyperalgesia in a rat neuropathic pain model. Neuroreport 2001; 12(10): 2079-2084.

13. Liang F, Liu M, Fu $X$, Zhou $X$, Chen $P$, Han $F$. Dexmedetomidine attenuates neuropathic pain in chronic constriction injury by suppressing NR2B, NFkappaB, and iNOS activation. Saudi Pharm J 2017; 25(4): 649-654.

14. Wang $W$, Cheng $H$, Gu $X$, Yin $X$. The natural flavonoid glycoside vitexin displays preclinical antitumor activity by suppressing NF-kappaB signaling in nasopharyngeal carcinoma. Onco Targets Ther 2019; 12(4461-4468.

15. Care IoLARCo, Animals UoL: Guide for the care and use of laboratory animals: US Department of Health and Human Services, Public Health Service, National, 1986.

16. Radat F, Margot-Duclot A, Attal N. Psychiatric comorbidities in patients with chronic peripheral neuropathic pain: a multicentre cohort study. Eur J Pain 2013; 17(10): 1547-1557.

17. Yalcin I, Barthas F, Barrot M. Emotional consequences of neuropathic pain: insight from preclinical studies. Neurosci Biobehav Rev 2014; 47:154-164.

18. Austin PJ, Wu A, Moalem-Taylor G. Chronic constriction of the sciatic nerve and pain hypersensitivity testing in rats. J Vis Exp 201261.

19. Hopkins SJ, Rothwell NJ. Cytokines and the nervous system. I: Expression and recognition. Trends Neurosci 1995; 18(2): 83-88.

20. Rothwell NJ, Hopkins SJ. Cytokines and the nervous system II: Actions and mechanisms of action. Trends Neurosci 1995; 18(3): 130-136.

21. Sweitzer S, Martin D, DeLeo JA. Intrathecal interleukin-1 receptor antagonist in combination with soluble tumor necrosis factor receptor exhibits an anti-allodynic action in a rat model of neuropathic pain. Neuroscience 2001; 103(2): 529-539.

22. Sorkin LS, Doom CM. Epineurial application of TNF elicits an acute mechanical hyperalgesia in the awake rat. J Peripher Nerv Syst 2000; 5(2): 96-100.

23. Marchand F, Perretti M, McMahon SB. Role of the immune system in chronic pain. Nat Rev Neurosci 2005; 6(7): 521-532.

24. Popiolek-Barczyk K, Mika J. Targeting the Microglial Signaling Pathways: New Insights in the Modulation of Neuropathic Pain. Curr Med Chem 2016; 23(26): 29082928. 
25. Katarzyna PB, Natalia K, Anna P, Wioletta M, Ewelina R, M. JA, Dominika P, Joanna M. Parthenolide Relieves Pain and Promotes M2 Microglia/Macrophage Polarization in Rat Model of Neuropathy. Neural Plasticity; 2015:1-15.
26. Popiolek-Barczyk K, Makuch W, Rojewska E, Pilat D, Mika J. Inhibition of intracellular signaling pathways NF$K B$ and MEK1/2 attenuates neuropathic pain development and enhances morphine analgesia. Pharmacol Rep; 66(5): 845-851. 